\title{
Effect of slow breathing on the blood pressure and the Valsalva ration in prehypertensive Indian students
}

\author{
Iryna Oleksandrivna Yepryntseva, \\ Larisa Semyonovna Shchyrova, \\ Vera Evgenievna Shekh* \\ Department of Human and \\ Animal Physiology, \\ V. N. Karazin Kharkiv National University, \\ 4 Svobody Sq, Kharkiv 61022, Ukraine
}

The purpose of this study was to evaluate the effect of slow breathing and prehypertension (PHT) on cardiovascular and HRV variables and on the Valsalva ratio (VR). ECG was recorded in 39 normotensives and 35 prehypertensives at 5 min resting and slow breathing ( 6 breaths/min) stages to obtain HR, LF and HF power; SBP and DBP were recorded at the end of each stage. The Valsalva manoeuvre was performed after resting and slow breathing stages. Two-way repeated MANOVA was used to test for the effects of PHT and slow breathing. Stepwise multiple linear regression analysis was used to reveal predictors of HR, SBP and DBP. The normotensives and the prehypertensives demonstrated reduction of SBP during slow breathing (117.95 \pm 0.73 vs. $115.18 \pm 0.91 \mathrm{~mm} \mathrm{Hg}, P=0.001$ and $130.09 \pm 0.08$ vs. $125.91 \pm 0.96 \mathrm{~mm} \mathrm{Hg}, P<0.001$, respectively). At rest, the VR was lower in prehypertensives $(1.69 \pm 0.05$ vs. $1.87 \pm 0.05, P=0.009)$. After slow breathing, the VR increased significantly only in prehypertensives ( $P=0.008)$, it was no longer different from that of normotensives $(1.82 \pm 0.06$ vs. $1.90 \pm 0.06, P=0.346)$. The LnLF power, interpreted according to our hypothesis described previously as sympathoinhibition, increased in both groups. Slow breathing reduced SBP in normotensives and prehypertensives as a result of an increase in sympathoinhibition in both groups and VR, considered as a surrogate marker of the baroreflex activity, in prehypertensives.

Keywords: Prehypertension, slow breathing, Valsalva ratio, HRV

\section{INTRODUCTION}

Hypertension has been well documented as a major risk factor and a leading cause of car-

\footnotetext{
* Corresponding author. Email: vshekh@karazin.ua, verashekh@gmail.com
}

diovascular disease and premature mortality (Chobanian et al., 2003). The impaired cardiovascular autonomic regulation plays a crucial role in the initiation and maintenance of hypertension; it also represents an important component in the pathophysiology of hypertension (Wu et al., 2008; Chobanian et al., 2003). 
It has been shown previously that the blood pressure (BP) can be reduced by lowering the respiratory rate and that the respiratory modulation may be of a therapeutic value in controlling hypertension (Joseph et al., 2005; Raupach et al., 2008; Sharma et al., 2011). Reduction of the respiratory rate lowered the blood pressure (BP) by a modulation of autonomic activity at both baroreflex and central levels (Benarroch, 1993; Joseph et al., 2005; Raupach et al., 2008; Sharma et al., 2011; Hilz et al., 2016). The changes in sympathetic and parasympathetic activity are provided via increased heart rate variability and baroreflex sensitivity (Grossman et al., 2001).

The analysis of heart rate variability (HRV) is a potentially useful tool for the evaluation of the autonomic nervous system activity and its contribution to the cardiac function in health and disease (Task Force of the European Society of Cardiology, and the North American Society of Pacing and Electrophysiology, 1996; Goldstein et al., 2011; Reyes et al., 2013). The spectral power of high frequency (HF) of HRV oscillations is widely accepted as a measure of the cardiac vagal activity; nevertheless, an interpretation of the spectral power of low frequency (LF) is more controversial. According to our hypothesis, LF HRV power is a measure of inhibition of the sympathetic nervous system activity elicited by baroreflex (Shekh, 2018).

The Valsalva manoeuvre (VM) tests the afferent, central, and efferent sympathetic and parasympathetic baroreflex pathways (Hilz et al., 2016). The Valsalva ratio (VR) is a measure of the heart rate (HR) response to $\mathrm{BP}$ changes resulting from the mechanical and cardiovascular effects of the Valsalva manoeuvre (Nahm and Freeman, 2007). There are four phases of $\mathrm{VM}$, indicating BP variations. In phase II, BP falls; this leads to parasympathetic withdrawal and sympathetic activation resulting in an increase in HR that reaches its maximum value. In phase IV, the $\mathrm{BP}$ reaches its maximum and the HR falls to the minimum level. The VR is calculated as HRmax/HRmin. A normal VR reflects an intact baroreceptormediated rise and fall in HR. A reduced VR reflects baroreceptor and cardiovagal and, possibly, sympathetic dysfunction. Thus, the Valsalva ratio provided us, at least in some cases, with a rapid and noninvasive tool in the evaluation of the subject's baroreflex and autonomic dysfunction (Emond, Lebel, 2002).

The purpose of this study was to evaluate the effect of slow breathing on the HR, systolic and diastolic blood pressure (SBP and DBP, respectively), VR, and HRV indices in normotensive and prehypertensive (PHT) subjects. Our basic study hypothesis was that slow breathing reduces the systolic blood pressure in prehypertensive subjects by means of an increase in the Valsalva ratio, a surrogate marker of baroreflex activity.

\section{MATERIALS AND METHODS}

Thirty-nine normotensive and 35 prehypertensive young men were recruited from the student population from India at V. N. Karazin Kharkiv National University. All of the participants gave written informed consents.

The resting stage was followed by the stage of slow breathing (six breaths per minute), each of $5 \mathrm{~min}$ in duration. The durations of the inspiratory and expiratory phases were set at 1:1. During the slow breathing stage, the subjects were asked to breathe as comfortably and effortlessly as possible, while keeping the lungs moving in accord with the audio signals generated by paced breathing test software for HRV analysis (CardioLab CS, XAI-Medica, Ukraine).

During the Valsalva manoeuvre after maximum inhalation, the subjects were asked to blow into a mouthpiece connected to an aneroid manometer and to maintain a pressure of $40 \mathrm{mmHg}$ for $10-15 \mathrm{~s}$ while the ECG was continuously recorded. A nose clip was used to prevent air leakage. The Valsalva ratio (VR) was calculated as the maximum HR, which occurs during the Valsalva manoeuvre in phase II, divided by the minimum $H R$, which occurs after the cessation of the Valsalva manoeuvre in phase IV (VR = max HR/min HR). The VR was recorded twice: immediately after the resting and slow breathing stages. 
The ECG was continually recorded and transferred to PC which produced automated measurements of ECG parameters (Shekh, 2016). LF and HF power expressed in absolute units was obtained by means of fast Fourier transformation and used for frequency-domain analysis.

Measurements of the systolic and the diastolic BP (SBP and DBP) were conducted using the automatic blood pressure digital sphygmomanometer (Nissei WS-1011, Nihon Seimitsu Sokki Co., Ltd, Japan). The blood pressure was measured at 4.5 minute of each stage.

Two-way repeated MANOVA with Bonferroni correction was used to test for possible effects of PHT, slow breathing, and their interaction on cardiovascular and HRV variables. The body mass index (BMI) was taken into account by means of two-way repeated MANCOVA. In the case of a significant main effect or/and significant factors interaction the simple effects were tested by means of SPSS command syntax. The stepwise multiple linear regression analysis was used to reveal the relative importance of LnLF, LnHF, and VR in HR, SBP and DBP, adjusted also for the presence of prehypertension, centred BMI, height, two- and three-way interactions. The null hypothesis was rejected at $P<0.05$. All analyses were conducted using SPSS 22.

\section{RESULTS}

There were no significant differences in age and height between normotensive and prehypertensive groups (Table 1). However, the BMI was

Table 1. Anthropometric characteristics of the participants

\begin{tabular}{ccc}
\hline & Normotensive & Prehypertensive \\
\hline$n$ & 39 & 35 \\
\hline Age, years & $20.31 \pm 0.27$ & $20.00 \pm 0.29$ \\
\hline Height, $\mathrm{m}$ & $1.70 \pm 0.01$ & $1.72 \pm 0.02$ \\
\hline BMI, $\mathrm{kg} / \mathrm{m}^{2}$ & $23.26 \pm 0.68$ & $26.18 \pm 0.72^{\star *}$ \\
\hline
\end{tabular}

Data are expressed as means $\pm \mathrm{SE}$; $n$, number of participants; ${ }^{* *} P<0.01$, vs. normotensives, were found from the general linear model (GLM) MANOVA. significantly higher in prehypertensive subjects then in normotensives. That is why two-way repeated MANCOVA with BMI as a covariate was used for the comparison of HR, SBP, DBP, LnLF, LnHF, and VR between normotensive and prehypertensive subjects.

Heart rate. The heart rate significantly increased during slow breathing in both normotensive and prehypertensive groups (Fig. 1). No differences were observed between normotensive and prehypertensive groups at rest and during slow breathing.

Systolic and diastolic blood pressure. As it was expected according to inclusion criteria, SBP and DBP were significantly higher in prehypertensive subjects (Figs. $2 \mathrm{~A}$ and $2 \mathrm{~B}$, respectively). Both normotensive and prehypertensive groups demonstrated a reduction of SBP during slow breathing (Fig. 2A). However, the SBP decreased at a higher significant level in prehypertensives. Unlike the systolic blood pressure, the DBP did not change statistically significantly during slow breathing (Fig. 2B).

LnLF and LnHF HRV power. The LnLF power increased significantly in both groups (Fig. 3A) during slow breathing, while LnHF was not affected statistically significantly (Fig. 3B).

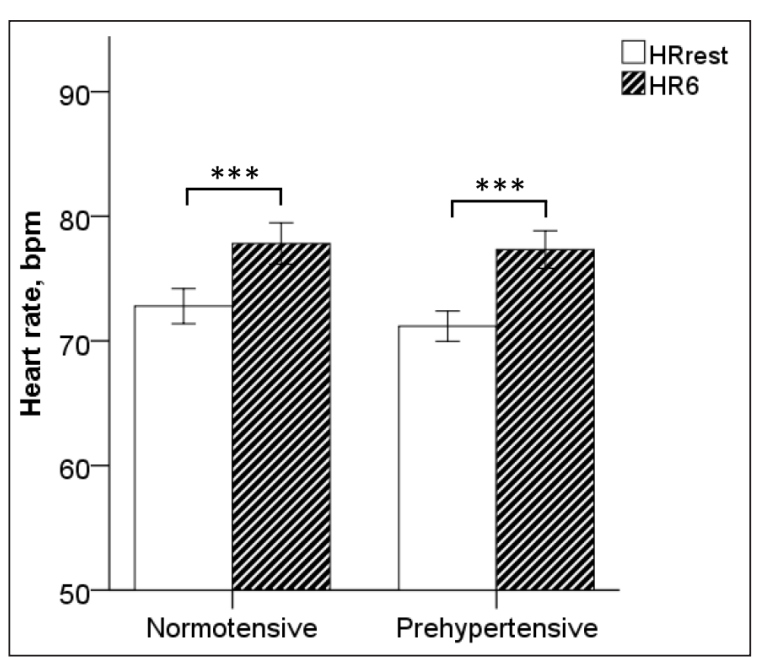

Fig. 1. Effect of slow breathing on the heart rate (HR) in normotensive and prehypertensive groups. ${ }^{* * *} P<0.001$, were found from the general linear model (GLM) two-way repeated measures MANOVA. Data are expressed as means \pm SE 


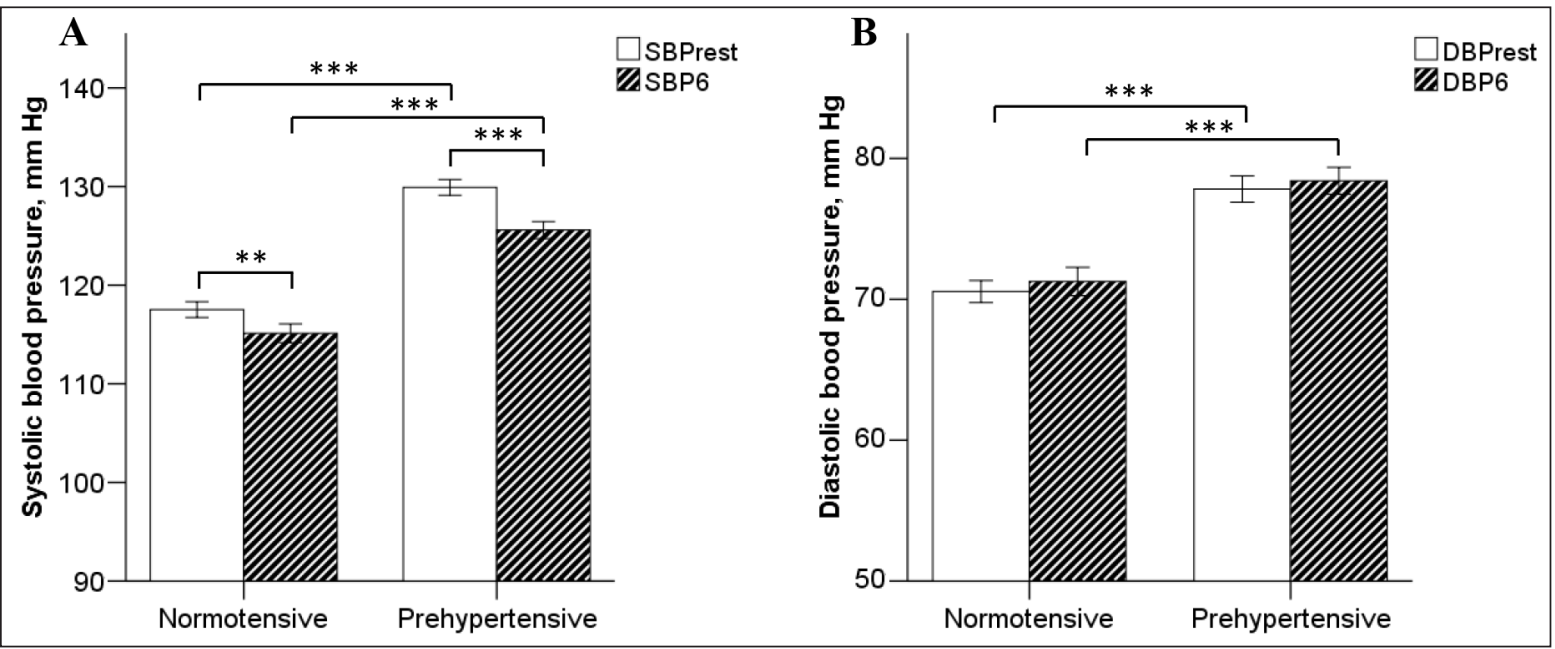

Fig. 2. Effect of slow breathing on SBP (A) and DBP (B) in normotensive and prehypertensive groups. ${ }^{* *} P<0.01 ;{ }^{* *} P<0.001$, were found from the general linear model (GLM) two-way repeated measures MANOVA. Data are expressed as means $\pm \mathrm{SE}$

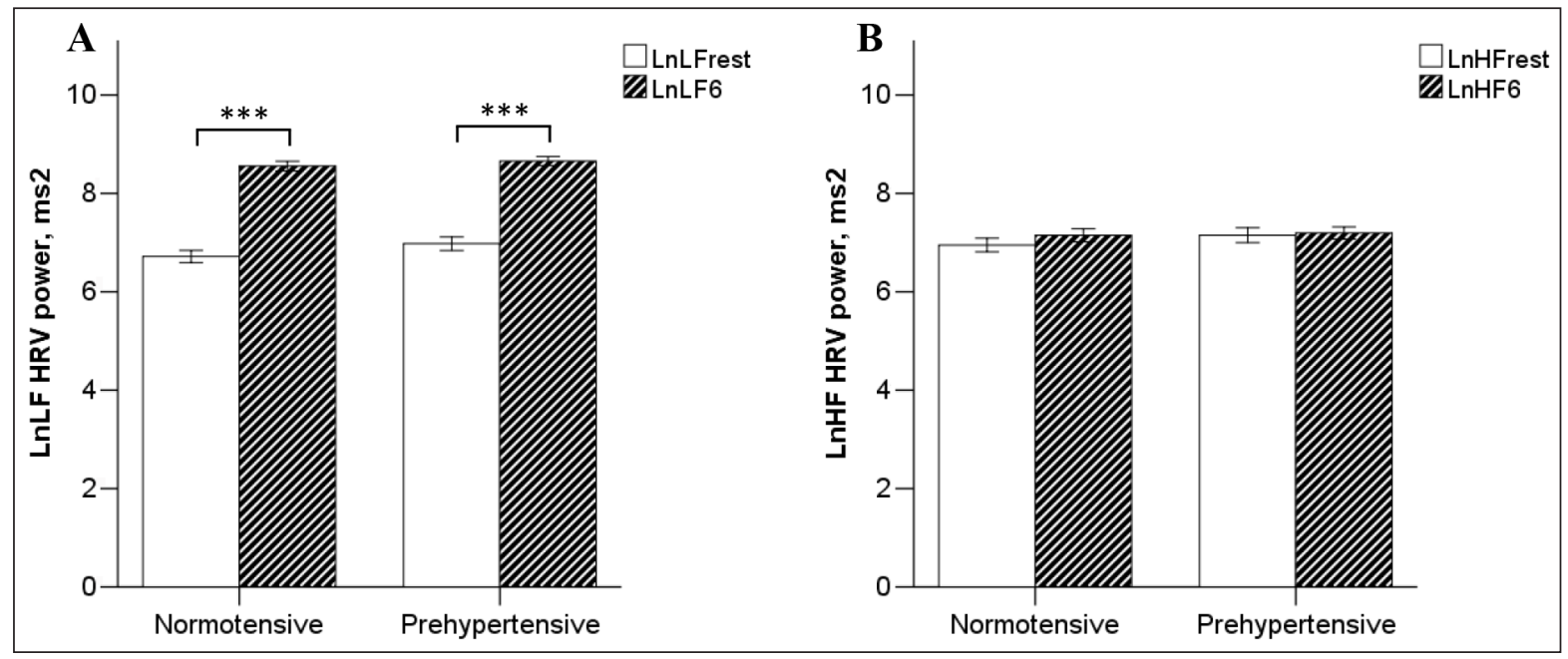

Fig. 3. Effect of slow breathing on LnLF (A) and LnHF (B) in normotensive and prehypertensive groups. ${ }^{\star * *} P<0.001$, were found from the general linear model (GLM) two-way repeated measures MANOVA. Data are expressed as means $\pm \mathrm{SE}$

Valsalva ratio. The baseline Valsalva ratio was lower in prehypertensives than in normotensives (Fig. 4). Five minutes of slow breathing resulted in a statistically significant increase of the Valsalva ratio only in prehypertensives, so that after slow breathing it was no longer reduced in the prehypertensive group compared with the normotensive one.

The inclusion of the BMI as a covariate into analysis (MANCOVA) did not change any of these differences and in some cases the level of statistical significance even increased (not shown).

The stepwise multiple linear regression analysis revealed that SBP and DBP were positively associated with prehypertension (PHT) at rest and during the slow breathing stage (Tables 2 and 3). The effect of PHT depended on LnLF and LnHF power at rest (LnLFrest and LnHFrest, respectively) (Table 2). In turn, 


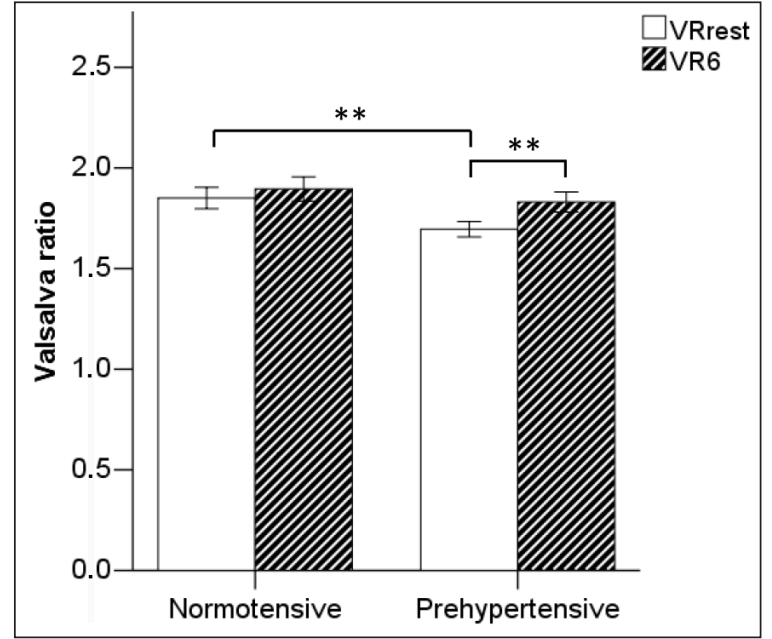

Fig. 4. Effect of slow breathing on the Valsalva ratio (VR) in normotensive and prehypertensive groups. ${ }^{* *} P<0.01$, were found from the general linear model (GLM) two-way repeated MANOVA. Data are expressed as means $\pm \mathrm{SE}$

Table 2. Predictors of HR, SBP, and DBP at the resting stage. Final stepwise regression coefficients of the models including centred variables, two-way, and three-way interactions. The reference category was normotensive subjects

\begin{tabular}{|c|c|c|c|c|}
\hline \multirow{2}{*}{ Models } & \multirow{2}{*}{$\begin{array}{c}\begin{array}{c}\text { Unstandardized } \\
\text { coefficients }\end{array} \\
\text { B } \\
\end{array}$} & \multicolumn{2}{|c|}{ Standardized coefficients } & \multirow{2}{*}{$P$} \\
\hline & & Standard error & Beta & \\
\hline \multicolumn{5}{|c|}{ Model 1, dependent variable: HRrest, $\mathrm{R}^{2}=\mathbf{0 . 1 0 2}$} \\
\hline (Constant, bpm) & 71.824 & 0.905 & & $<0.001$ \\
\hline LnHFrest, Lnms2 & -2.888 & 1.011 & -0.319 & 0.006 \\
\hline \multicolumn{5}{|c|}{ Model 2, dependent variable: SBPrest, $\mathrm{R}^{2}=0.731$} \\
\hline (Constant, mm Hg) & 118.212 & 0.664 & & $<0.001$ \\
\hline PHT & 12.928 & 1.030 & 0.855 & $<0.001$ \\
\hline $\begin{array}{l}\text { PHT }^{\star} \text { LnLFrest }^{\star} \text { LnHFrest, } \\
\text { Lnms } 2^{\star} \text { Lnms } 2\end{array}$ & -2.271 & 1.004 & -0.154 & 0.027 \\
\hline $\begin{array}{l}\text { LnLFrest }{ }^{\star} \text { VRrest }{ }^{\star} \text { Height, } \\
\text { Lnms } 2^{\star} \mathrm{m}\end{array}$ & -117.395 & 42.984 & -0.174 & 0.008 \\
\hline $\begin{array}{l}\text { LnHFrest }{ }^{\star} \text { VRrest }{ }^{\star} \text { BMI, } \\
\text { Lnms } 2^{\star} \mathrm{kg} / \mathrm{m}^{2}\end{array}$ & -2.359 & 0.647 & -0.230 & 0.001 \\
\hline \multicolumn{5}{|c|}{ Model 3, dependent variable: DBPrest, $\mathbf{R}^{2}=0.339$} \\
\hline (Constant, $\mathrm{mm} \mathrm{Hg}$ ) & 71.000 & 0.773 & & $<0.001$ \\
\hline PHT & 6.829 & 1.124 & 0.582 & $<0.001$ \\
\hline
\end{tabular}

$N=74$; PHT, prehypertension; VRrest, Valsalva ratio measured after the resting stage; HRrest, heart rate at the resting stage; SBPrest and DBPrest, systolic and diastolic blood pressure at the resting stage; LnLFrest and LnHFrest, natural logarithm of low and high frequency power at the resting stage; BMI, body mass index.

the effect of LnLFrest depended on resting VR (VRrest) and height, while the effect of LnHFrest depended on VRrest and BMI. However, during the slow breathing stage the effect of PHT on SBP (SBP6) depended on VR (VR6) only (Table 3).
At rest, HR was negatively associated with LnHFrest only (Table 2). During slow breathing, HR was negatively associated with LnHF (LnHF6), similarly to the resting stage. Meanwhile, it was also negatively associated with LnLF (LnLF6) and positively associated with 
Table 3. Predictors of HR, SBP and DBP at the slow breathing (6 breaths/min) stage. Final stepwise regression coefficients of the models including centred variables, two-way and three-way interactions. The reference category was normotensive subjects

\begin{tabular}{|c|c|c|c|c|}
\hline \multirow{2}{*}{ Models } & \multicolumn{2}{|c|}{ Unstandardized coefficients } & \multirow{2}{*}{$\begin{array}{c}\text { Standardized coefficients } \\
\text { Beta }\end{array}$} & \multirow{2}{*}{$P$} \\
\hline & B & Standard error & & \\
\hline \multicolumn{5}{|c|}{ Model 1, dependent variable: $H R 6, \mathrm{R}^{2}=0.527$} \\
\hline (Constant, bpm) & 77.477 & 0.818 & & $<0.001$ \\
\hline VR6 & 9.502 & 2.475 & 0.351 & $<0.001$ \\
\hline LnLF6, Lnms2 & -4.675 & 1.815 & -0.267 & 0.012 \\
\hline LnHF6, Lnms2 & -3.383 & 1.303 & -0.277 & 0.012 \\
\hline VR6 ${ }^{\star}$ Height, $\mathrm{m}$ & -108.631 & 33.013 & -0.291 & 0.002 \\
\hline VR6 ${ }^{\star} \operatorname{LnLF} 6, \mathrm{~ms} 2$ & -12.182 & 5.129 & -0.229 & 0.020 \\
\hline $\begin{array}{l}\mathrm{VR}^{*} \mathrm{LnLF} 6^{*} \mathrm{BMI}, \\
\mathrm{ms}^{2}{ }^{\star} \mathrm{kg} / \mathrm{m}^{2}\end{array}$ & -5.499 & 1.341 & -0.450 & $<0.001$ \\
\hline $\begin{array}{c}\mathrm{VR} 6^{\star} \mathrm{LnHF} 6^{*} \mathrm{BMI}, \\
\mathrm{ms} 2^{\star} \mathrm{kg} / \mathrm{m}^{2}\end{array}$ & 2.678 & 1.039 & 0.290 & 0.012 \\
\hline
\end{tabular}

\begin{tabular}{ccccc}
\hline \multicolumn{5}{c}{ Model 2, dependent variable: $\mathbf{S B P 6 , \mathbf { R } ^ { \mathbf { 2 } } \mathbf { 0 . 5 2 3 }}$} \\
\hline (Constant, $\mathrm{mm} \mathrm{Hg})$ & 115.179 & 0.874 & $<0.001$ \\
\hline PHT & 10.393 & 1.278 & 0.670 & $<0.001$ \\
\hline PHT ${ }^{*}$ VR6 & -8.271 & 3.210 & -0.212 & 0.012 \\
\hline \multicolumn{5}{c}{ Model 3, dependent variable: $\mathbf{D B P 6 , \mathbf { R } ^ { 2 }}=\mathbf{0 . 4 1 7}$} \\
\hline (Constant, $\mathrm{mm} \mathrm{Hg})$ & 70.816 & 0.801 & $<0.001$ \\
\hline PHT & 7.791 & 1.171 & 0.608 & $<0.001$ \\
\hline Height, $\mathrm{m}$ & -28.982 & 8.386 & -0.316 & 0.001 \\
\hline
\end{tabular}

$N=74$; PHT, prehypertension; VR6, Valsalva ratio measured after the slow breathing (6 breaths/min) stage; HR6, heart rate at the slow breathing ( 6 breaths/min) stage; SBP6 and DBP6, systolic and diastolic blood pressure at the slow breathing ( 6 breaths/min) stage; LnLF6 and LnHF6, natural logarithm of low and high frequency power at the slow breathing (6 breaths/min) stage; BMI, body mass index.

VR6 (Table 3). The effect of LnLF6 and LnHF6 on the HR6 depended on VR6 and BMI, and the effect VR6 on HR6 depended on height.

\section{DISCUSSION}

The current study, showing an increase in the Valsalva ratio and a decrease in the systolic blood pressure in prehypertensive subjects during slow breathing, extends our previous observations of the effects of slow breathing on the blood pressure and HRV (Shekh, 2017).

Since hypertension has been well documented as a major risk factor for cardiovascular diseases, the search for both pharmacologi- cal and non-pharmacological methods is one of the main tasks of medical and physiological scientific researches. In congruence with previous researches, in the current study the lowering of the respiratory rate to 6 breaths $/ \mathrm{min}$ led to a significant reduction of systolic blood pressure in the prehypertensive group. The decrease of the SBP by means of the respiratory modulation was shown in patients with chronic heart failure (Bernardi et al., 2002), essential hypertension (Joseph et al., 2005), in hypoxic patients with chronic obstructive pulmonary disease (COPD) (Raupach et al., 2008), and in young men from different ethnic/racial populations developing hypertension (Shekh, 2017). 
However, unlike in previous reports, in the current study the SBP decreased in normotensive subjects as well. This finding may be explained partially by the difference in age, ethnicity, the technique of respiration modulation, and a relatively large sample size in the current research. In addition, some previous studies reported a trend of the decrease of the SBP in normotensives, but these differences did not reach a significant level.

Despite slow breathing being the most popular approach among the non-pharmacological methods used for lowering of the blood pressure, specific mechanisms involved in the reduction of SBP remain unclear up until now. However, it was proposed that modulation of a set of reflexes, such as lung inflation reflexes, baroreflex, chemoreflex, and central mechanisms contributed to the lowering of the SBP during slow breathing (Bernardi et al., 2002; Joseph et al., 2005; Raupach et al., 2008; Sharma et al., 2011). According to our study hypothesis indicating that modulation of baroreflex activity is the main contributor to the lowering of the systolic blood pressure, the VR has been recorded before and immediately after the slow breathing procedure.

The VR is a measure of the HR response to $\mathrm{BP}$ changes resulting from the mechanical and cardiovascular effects of the Valsalva manoeuvre (Nahm, Freeman, 2007). This HR response and, namely, VR, are provided by baroreceptors, parasympathetic and sympathetic nerve fibres, tractus solitarii, and rostral central autonomic network (Benarroch, 1993; Emond, Lebel, 2002; Nahm, Freeman, 2007; Hilz et al., 2016), and may be considered a surrogate marker of baroreflex activity and possibly baroreflex sensitivity. A normal VR reflects an intact baroreceptor-mediated rise and fall in the HR, while a reduced VR reflects baroreceptor, cardiovagal, and possibly sympathetic dysfunction (Nahm, Freeman, 2007). Thus the fact that the baseline Valsalva ratio was lower in prehypertensive subjects indicates that prehypertensives had a reduced baroreflex activity. This finding supports the hypothesis that hypertension is etiologically linked to sympathetic activation and associated autonomic imbalance as a result of reduced baroreflex sensitivity (Joseph et al., 2005; Raupach et al., 2008; Sharma et al., 2011).

During slow breathing, the Valsalva ratio increased significantly only in prehypertensive subjects in congruence with the data of other authors who reported that slow breathing increased arterial baroreflex sensitivity in patients with chronic heart failure (Bernardi et al., 2002), that slow breathing improved arterial baroreflex sensitivity and decreased the blood pressure in essential hypertension (Joseph et al., 2005), and that slow breathing reduced sympathoexcitation in COPD (Raupach et al., 2008). As a result, the VR was no longer different between normotensives and prehypertensives, possibly indicating an improvement of baroreflex sensitivity in prehypertensives.

The HRV analysis is a potentially useful tool for the evaluation of autonomic nervous system activity (Task Force of the European Society of Cardiology, and the North American Society of Pacing and Electrophysiology. Heart rate variability. Standards of measurement, physiological interpretation, and clinical use, 1996; Goldstein et al., 2011; Reyes et al., 2013). The spectral power of HF HRV power is widely accepted as a measure of the cardiac vagal activity, while an interpretation of LF HRV power is more controversial. We proceeded from the assumption that LF HRV power represents sympathoinhibitory arm of baroreflex (Shekh, 2018). In congruence with previous reports, in the current study the LnLF power was increased during slow breathing in both groups (Pitzalis et al., 1998; Wang, 2013; Shekh, 2017). It is proposed that this evaluation of LnLF power represents an increase in inhibitory influences exerted on the sympathetic nervous system. As a result, SBP decreases in normotensive and prehypertensive subjects.

As it was expected, multiple regression analysis revealed that SBPrest was positively associated with prehypertension; however, in the case of high values of LnLFrest and LnHFrest power indicating high values of parasympathetic activity and sympathoinhibition, the effect of prehypertension was weaker. In turn, the effect of 
LnLFrest and LnHFrest depended on VRrest, a surrogate marker of baroreflex activity. However, the most important predictors of SBP6 remaining in the model were prehypertension and prehypertension by VR6 interaction indicating that after slow breathing the belonging to prehypertensive group is determined by baroreflex activity.

Unlike the SBP, the heart rate and the DBP did not drop in any group during slow breathing in agreement with most of previous reports (Bernardi et al., 2002; Joseph et al., 2005; Raupach et al., 2008; Shekh, 2017). Even more, the HR was significantly increased in both groups. A possible explanation of this observation is that due to coupling of the SBP and the HR by baroreflex and increase of baroreflex activity during slow breathing, reduction of the SBP led to the increase of HR. The baseline HR was negatively associated only with the LnHF power, indicating predomination of parasympathetic regulation at rest. But during slow breathing it was positively associated with the VR, indicating that the high activity of baroreflex during the reduction of the SBP lead to the increase of the HR; and negatively associated with LnLF and LnHF power, as sympathoinhibitory and cardiovagal arms of baroreflex, respectively, indicating that a high level of the sympathoinhibition and cardiovagal activity decreases the HR. During slow breathing, the effect of the VR on the HR depended on the LnLF power, LnHF power, height, and the BMI, indicating that the baroreflex activity (1) increases the HR in tall subjects less than in short ones; (2) increases the HR less in subjects with high sympathoinhibitory activity, and it is especially for obese individuals; (3) increases HR less in lean subjects with high parasympathetic activity. As the HR is one of the determinants of the DBP, reduction of the DBP was not observed like in the case of the SBP.

\section{CONCLUSIONS}

The slowing of breathing to 6 breaths/min significantly reduced the systolic blood pressure in normotensive and prehypertensive Indian students as a result of an increase in sympathoinhibition in both groups, and VR, considered as a surrogate marker of baroreflex activity, in prehypertensives.

\section{ACKNOWLEDGEMENTS}

We are grateful to Professor V. A. Bondarenko for the delicate leadership and given opportunity. Thanks to A. E. Zhuikova and O. V. Vyazovska for technical support and to the research participants for their enthusiastic participation, time, and patience with this study.

Received 20 June 2018 Accepted 5 February 2019

\section{References}

1. Benarroch EE. The central autonomic network: functional organization, dysfunction, and perspective. Mayo Clin Proc. 1993; 68(10): 988-1001.

2. Bernardi L, Porta C, Spicuzza L, Bellwon J, Spadacini G, Frey AW, Yeung LYC, Sanderson JE, Pedretti R, Tramarin R. Slow breathing increases arterial baroreflex sensitivity in patients with chronic heart failure. Circulation. 2002; 105(2): 143-45.

3. Chobanian AV, Bakris GL, Black HR, Cushman WC, Green LA, Izzo JL, Jones DW, Materson BJ, Oparil S, Wright JT, Roccella EJ. Joint National Committee on Prevention, Detection, Evaluation, and Treatment of High Blood Pressure; National Heart, Lung, and Blood Institute; National High Blood Pressure Education Program Coordinating Committee. Seventh report of the Joint National Committee on prevention, detection, evaluation, and treatment of high blood pressure. Hypertension. 2003; 42(6): 1206-52.

4. Emond D, Lebel M. Orthostatic hypotension and Holmes-Adie syndrome. Usefulness of the Valsalva ratio in the evaluation of baroreceptor dysfunction. J Hum Hypertens. 2002; 16(9): 661-2. 
5. Goldstein DS, Bentho O, Park MY, Sharabi Y. Low-frequency power of heart rate variability is not a measure of cardiac sympathetic tone but may be a measure of modulation of cardiac autonomic outflows by baroreflexes. Exp Physiol. 2011; 96(12): 1255-61.

6. Grossman E, Grossman A, Schein MH, Zimlichman R, Gavish B. Breathing-control lowers blood pressure. J Hum Hypertens. 2001; 15(4): 263-9.

7. Hilz MJ, Liu M, Koehn J, Wang R, Ammon F, Flanagan SR, Hösl KM. Valsalva maneuver unveils central baroreflex dysfunction with altered blood pressure control in persons with a history of mild traumatic brain injury. BMC Neurology. 2016; 16: 61.

8. Joseph CN, Porta C, Casucci G, Casiraghi N, Maffeis M, Rossi M, Bernardi L. Slow breathing improves arterial baroreflex sensitivity and decreases blood pressure in essential hypertension. Hypertension. 2005; 46(4): 714-8.

9. Nahm FK, Freeman R. Autonomic Nervous System Testing. In: Blum AS, Rutkove SB, editors. The clinical neurophysiology primer. $\mathrm{Hu}-$ mana Press Inc. 2007; 447-60.

10. Pitzalis MV, Mastropasqua F, Massari F, Passantino A, Colombo R, Mannarini A, Forleo C, Rizzon P. Effect of respiratory rate on the relationships between RR interval and systolic blood pressure fluctuations: a frequency-dependent phenomenon. Cardiovasc Res. 1998; 38(2): 332-9.

11. Raupach T, Bahr F, Herrmann P, Luethje L, Heusser K, Hasenfuss G, Bernardi L, Andreas S. Slow breathing reduces sympathoexcitation in COPD. Eur Respir J. 2008; 32(2): 387-92.
12. Reyes PGA, Langewitz W, Mulder LJ, van Roon A, Duschek S. The utility of low frequency heart rate variability as an index of sympathetic cardiac tone: A review with emphasis on a reanalysis of previous studies. Psychophysiology. 2013; 50(5): 477-87.

13. Sharma M, Frishman WH, Gandhi K. RESPeRATE. Nonpharmacological Treatment of Hypertension. Cardiology in Review. 2011; 19(2): 47-51.

14. Shekh VE. Sex and ethnic/racial differences in blood pressure and heart rate variability during orthostatic testing in young healthy individuals. J Phys Pharm Adv. 2016; 6(3): 846-59.

15. Shekh VE. Slow breathing has unequal effects on prehypertensives from different ethnic/ racial groups. Ann Med Physiol. 2017; 1(1): 9-15.

16. Shekh VE. LF HRV power as an index of sympathetic inhibition. FASEB J. 2018; 32(1): lb460.

17. Task Force of the European Society of Cardiology, and the North American Society of Pacing and Electrophysiology. Heart rate variability. Standards of measurement, physiological interpretation, and clinical use. Eur Heart J. 1996; 17(3): 354-81.

18. Wang YP, Kuo TB, Lai CT, Chu JW, Yang CC. Effects of respiratory time ratio on heart rate variability and spontaneous baroreflex sensitivity. J Appl Physiol. 2013; 115(11): 1648-55.

19. Wu JS, Lu FH, Yang YC, Lin TS, Chen JJ, $\mathrm{Wu} \mathrm{CH}$, Huang $\mathrm{YH}$, Chang CJ. Epidemiological study on the effect of pre-hypertension and family history of hypertension on cardiac autonomic function. J Am Coll Cardiol. 2008; 51(19): 1896-901. 
Iryna Oleksandrivna Yepryntseva, Larisa Semyonovna Shchyrova, Vera Evgenievna Shekh

\section{LĖTO KVĖPAVIMO POVEIKIS PREHIPER- TENZINIŲ INDIJOS STUDENTŲ KRAU- JOSPŪDŽIUI IR VALSALVOS SANTYKIUI}

\section{Santrauka}

Tyrimo tikslas buvo nustatyti lèto kvèpavimo poveiki prehipertenzinei (PHT) būklei, širdies ir kraujagyslių sistemai, širdies ritmo dažnio variabilumui (RDV) ir Valsalvos santykiui (VS). Elektrokardiograma (EKG) buvo atlikta 39 normotenzinès ir 35 prehipertenzinès büklès asmenims ramybès ir lèto kvejpavimo metu (6 ikkẻpiai per minutę); ŠD, ŽD ir AD stiprumas registruotas kas 5 minutes, SKS ir DKS registruoti kiekvieno etapo pabaigoje. Valsalvos manevras atliktas po poilsio ir lèto kvejpavimo etapų. Dvikrypčiais kartotiniais matavimais MANOVA siekta nustatyti leto kveepavimo poveikị PHT būklei. ŠD, SKS ir DKS rodikliams atskleisti taikyta daugialypé linijinè regresinè analizè.
Nustatytas SKS sumažéjimas lèto kvépavimo metu: normotenzinès būklès atveju $-117,95 \pm 0,73$ vs. $115,18 \pm 0,91 \mathrm{~mm} \mathrm{Hg}, P=0,001$ ir 130,09 $\pm 0,08$; PHT būklès atveju - 125,91 $\pm 0,96 \mathrm{~mm} \mathrm{Hg}$, $P<0,001$. Poilsio metu VS buvo mažesnis esant prehipertenzinei būklei - 1,69 $\pm 0,05$; normotenzinès būklès atveju $-1,87 \pm 0,05, P=0,009$. Po lèto kvèpavimo VS reikšmingai padidèjo tik prehipertenzinès būklès asmenims $(P=0,008)$, jis nebesiskyrè nuo normotenzinès būklès $(1,82 \pm 0,06$ vs. $1,90 \pm 0,06$, $P=0,346)$. LnLF galia, interpretuota pagal anksčiau mūsų iškeltą simpatinio slopinimo hipotezę, padidèjo abiejose grupèse. Lètas kvèpavimas sumažino normotenzinès ir prehipertenzinès būklių SKS, nes abiejose grupèse sustiprèjo simpatinis slopinimas. Esant prehipertenzinei būklei, lètas kvejpavimas sumažino VS, kuris laikomas baroreflekso aktyvumo pakaitiniu žymeniu.

Raktažodžiai: prehipertenzija, lètas kvėpavimas, Valsalvos santykis, RDV 